\title{
THE EFFECT OF TANNIN SUPPLEMENTATION OF MID-LACTATION DAIRY COWS DIETS ON METABOLIC PROFILE PARAMETERS AND PRODUCTION CHARACTERISTICS
}

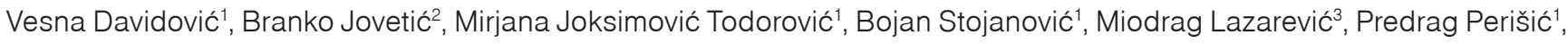 \\ Mihailo Radivojević4 ${ }^{\text {, Milan Maletić }}{ }^{3}$, Aleksandar Miletić ${ }^{5}$ \\ ${ }^{1}$ Faculty of Agriculture, University of Belgrade, Nemanjina 6, 11080 Zemun, ${ }^{2}$ Veterinary Station PKB, Industrijsko naselje bb, 11213 Padinska \\ Skela, ${ }^{3}$ Faculty of Veterinary Medicine, University of Belgrade, Bulevar oslobođenja, 11000 Belgrade, ${ }^{4}$ Faculty of Ecological Agriculture, \\ Educons University, Vojvode Putnika 87, 21208 Sremska Kamenica, ${ }^{5}$ Institute PKB Agroekonomik, Industrijsko naselje bb, 11213 Padinska \\ Skela, Serbia \\ ${ }^{*}$ Corresponding author, E-mail:vesnadv@agrif.bg.ac.rs
}

\begin{abstract}
The aim of this study was to examine the effect of using tannin supplement in ration for mid-lactation dairy cows ( $90 \pm 17$ days in milk) and the number of lactation on metabolic profile parameters values. Additionally, the effect of tannin supplementation on cows' production characteristics in the $2^{\text {nd }}$ lactation was evaluated. Research was conducted on 80 Holstein cows divided into two groups of 40 cows (control and experimental group) that included 16 cows in $2^{\text {nd }}$ and 12 in $3^{\text {rd }}$ and $4^{\text {th }}$ lactation. The tannin supplement Tanimil SCC ( $40 \mathrm{~g} / \mathrm{cow} /$ day; $40 \%$ of tannins) was added in the total mixed ration (TMR) of experimental group, while the control group of cows was fed ration without the tannin supplement. The trial lasted 60 days. Dairy cows, fed diet supplemented with tannin, had markedly lower values $(P<0.05)$ of $B$-hydroxybutyrate concentration $(0.79$ vs. $0.96 \mathrm{mmol} / \mathrm{L}$ ) and lower blood urea concentration ( $5.89 \mathrm{vs} .6 .93 \mathrm{mmol} / \mathrm{L}$ ). Difference in the blood glucose concentrations (3.92 vs. $3.89 \mathrm{mmol} / \mathrm{L}$ ) was not significant. The lactation number had no significant effect on values of metabolic profile parameters (concentration of glucose, B-hydroxybutyrate and urea). The effect of interaction of lactation number and tannin supplement on the values of examined parameters of metabolic profile was not significant. Supplementation of tannin in the diet for cows in the second lactation, had a positive effect $(\mathrm{P}<0.05)$ on the milk yield $(4.42 \%)$ and yield of $4 \%$ fat corrected milk (FCM, 5.24\%). The use of tannin, improved concentration (3.20 vs. 3.12\%) and yield (from 1.16 to $1.24 \mathrm{~kg} /$ day) of milk protein ( $\mathrm{P}<0.05$ ). Addition of tannin also improved concentration and yield of milk fat, as well as the concentration of lactose. The supplementation of Tanimil SCC to mid-lactation dairy cows had a positive impacts on reduction of blood content of B-hydroxybutyrate and urea, and improved productive performances of cows in the second lactation.
\end{abstract}

Key words: tannins; lactating cows; nutrition; metabolic profile; milk yield and composition

\section{Introduction}

Maximizing animals' daily gain or milk yield per unit of protein intake is based on improved dietary protein utilization (1). However, one of the main problems in dairy cows nutrition is the excess of ruminal degradable and deficiency of undegradable protein in ration, in absolute and relative figures, relative to the dietary content of carbohydrate fractions and rates of their ruminal degradation.

Received: 30 March 2018

Accepted for publication: 4 November 2019
Tannins have the potential to protect proteins from ruminal degradation, and to decrease rate of $\mathrm{NH}_{3}-\mathrm{N}$ accumulation in the ruminal content, which makes them suitable additives for dairy cows diets with surplus of ruminal degradable protein, and even nonprotein nitrogen (2). High concentrations of tannins (usually higher than $50 \mathrm{~g} / \mathrm{kg} \mathrm{DM}$ ) reduce voluntary feed intake and nutrient digestibility to a great extent because they decrease feed palatability, slow down digestion, and development of conditional repulsiveness (3). Intake of low to medium quantity of condensed tannins (CT) (10-40 g/kg DM) may improve feed 
digestion and feed conversion mainly due to the reduction of ruminal protein degradation which is related with lower production of $\mathrm{NH}_{3}-\mathrm{N}$ and higher availability of essential amino acids and non-ammonia nitrogen for absorption in the small intestine (4). Tannins modify the ruminal fermentation by formation of poorly degradable complexes with proteins that are stable within the $\mathrm{pH}$ range of 3.5 to 7.0 , and also by reducing quantity of immediately degradable fractions. Such formed complexes, protect proteins from microbial hydrolysis and deamination in the rumen, and increased the quantity of proteins that are degraded in abomasum and small intestine (2). These secondary plant metabolites have also a property to form reversible and irreversible complexes with polysaccharides (cellulose, hemicelluloses, starch and pectin), alkaloids, nucleic acids and minerals (5).

Values of some metabolic profile parameters, $\beta$-hydroxybutyrate (BHBA) and urea can serve to estimate cows' health status and to measure the adequacy of dietary protein levels as well as nitrogen utilization efficiency. Subclinical ketosis is characterized by elevated serum $\beta$-hydroxybutyrate concentrations $(>1.0$ to 1.4 $\mathrm{mmol} / \mathrm{l}$ ) in the absence of clinical signs of ketosis (6). All precursors for the synthesis of milk components, reach mammary gland by blood, so the composition of the milk to the great extent depends of their blood content. Monitoring levels of blood urea nitrogen (BUN) or milk urea nitrogen (MUN) may provide information on how well the ratio of rumen degradable proteins is balanced with energy availability to optimize rumen microbial protein synthesis, as it is known that imbalance in protein and carbohydrate degradabilities may result in suboptimal animal health and lower production (7). However, the increased content of BUN and MUN could be the result of nitrogen inefficiency caused by the surplus of tissues protein supply (8). Szczechowiak et al. (9) reported that using condensed tannins in cattle nutrition significantly increased blood glucose level while concentration of BHBA was unchanged.

Several authors found that using condensed tannins in ruminant nutrition increases milk yield, milk protein, lactose and fat, decreases blood and milk urea nitrogen concentration (1, $10,11,12)$, and protects animal health (13). However, Benchaar and Chouinard (14), Aguerre et al. (15) and Broderick et al. (16) did not find significant effect of low tannins content in cows ration, especially on the feed intake, milk yield, protein content and composition, $\mathrm{N}$ concentration, lactose, fat content and fatty acid profile in milk.

The objective of this study was to investigate the effects of supplementing diet for the mid-lactation dairy cows with different lactation number with tannin, and influence of these factors on some blood metabolic profile parameters concentration in cows, and also to explore the effects of tannin supplementation on the production performances of cows in the second lactation.

\section{Materials and methods}

\section{Animals and the diets}

The trial was conducted on the commercial dairy cattle farm (PKB Corporation -Padinska Skela), Serbia. Research was conducted on 80 Holstein cows (32 in $2^{\text {nd }}, 24$ in $3^{\text {rd }}$ and 24 in the $4^{\text {th }}$ lactation) that were housed in the individual tie stalls, divided into two groups of 40 cows (control and experimental group) that included 16 cows in $2^{\text {nd }}$ and 12 in $3^{\text {rd }}$ and $4^{\text {th }}$ lactation. Experiment was designed as a $2 \times 3$ factorial arrangement of treatments (two rations, with and without added tannin, and three lactation number) for determination the effect on metabolic profile of cows, and as one factorial arrangement with two treatments (ration with and without added tannin) to estimate the effect on production performances of the $2^{\text {nd }}$ lactation cows. The experimental groups were equalized according to the lactation number, stage of lactation (mid-lactation, $90 \pm 17$ days in milk), the average milk yield $(38.6 \pm 2.2 \mathrm{~kg} / \mathrm{d})$ and body condition score $(3.2 \pm 0.15)$. A trial period lasted for 60 days. Cows were offered a total mixed ration (TMR) two times a day (in the morning and evening) that were prepared according to the nutritional value and energy content, and balanced to meet nutritional requirements of cows for maintenance and milk production (Table 1). Cows in the control group were fed ration without supplemented tannin, while in TMR for experimental group, tannin (from horse-chestnut bark) based supplement "Tanimil SCC“ (Tanin, Sevnica, Slovenia) was added in quantity of $40 \mathrm{~g} /$ cow/day (contained 40\% tannins). Rations were formulated for the cows of $600 \mathrm{~kg} \mathrm{BW}$ with milk production of $39 \mathrm{~kg} /$ day, containing $3.7 \%$ milk fat 
Table 1: Composition and nutritional value of the total mixed rations for dairy cows

\begin{tabular}{lcc}
\hline Ingredients, kg DM/day & Control group & Experimental group \\
\hline Alfalfa hay & 1.78 & 1.78 \\
Alfalfa haylage & 1.77 & 1.77 \\
Triticale silage & 0.75 & 0.75 \\
Corn silage & 6.73 & 6.73 \\
Beet pulp, ensiled & 0.46 & 0.46 \\
Brewers grain & 1.09 & 1.09 \\
Beet molasses & 1.56 & 1.56 \\
Barley grain & 0.89 & 0.89 \\
Corn grain & 2.73 & 2.73 \\
Wheat grain & 1.33 & 1.33 \\
Canola meal & 1.28 & 1.28 \\
Soybean full-fat, extruded & 1.41 & 1.41 \\
Soybean cake & 1.86 & 1.86 \\
Calcium carbonate & 0.09 & 0.09 \\
Monocalcium phosphate & 0.04 & 0.04 \\
Sodium bicarbonate & 0.10 & 0.10 \\
Salt & 0.07 & 0.07 \\
Vitamin - mineral mix ${ }^{1}$ & 0.18 & 0.18 \\
Tanimil SCC & - & 0.04 \\
\hline
\end{tabular}

Nutrient composition

\begin{tabular}{lc}
\hline DM, kg & 24.1 \\
\hline CP, g/kg DM & 178.0 \\
RDP, g/kg DM & 114.0 \\
RUP, g/kg DM & 64.0 \\
NDF, g/kg DM & 315.0 \\
Forage NDF, g/kg DM & 223.0 \\
ADF, g/kg DM & 192.0 \\
NFC, g/kg DM & 423.0 \\
EE, g/kg DM & 44.0 \\
Ca, g/kg DM & 6.0 \\
P, g/kg DM & 4.0 \\
Energy value NE $\mathrm{LJ} / \mathrm{kg} \mathrm{DM}$ & 6.65 \\
\hline
\end{tabular}

${ }^{1}$ Mixture of vitamins and trace elements, $1 \mathrm{~kg}$ contains: Vitamin A - $500000 \mathrm{IU}$, Vitamin D - $300000 \mathrm{IU}, \mathrm{Vitamin} \mathrm{E}-1600 \mathrm{IU}, \mathrm{Mg}-6.7 \mathrm{~g}, \mathrm{~S}-1 \mathrm{~g}$, $\mathrm{Fe}-1000 \mathrm{mg}, \mathrm{Cu}-1300 \mathrm{mg}, \mathrm{Mn}-6600 \mathrm{mg}, \mathrm{Zn}-5500 \mathrm{mg}, \mathrm{J}-90 \mathrm{mg}$, Se - $15 \mathrm{mg}$, and Co - $5 \mathrm{mg}$.

DM: dry matter; CP: crude protein; RDP: rumen-degradable protein; RUP: rumen-undegradable protein; NDF: neutral detergent fibre; ADF: acid detergent fibre; NFC: non-fibre carbohydrates; EE: ether extract; Ca: calcium; P: phosphorus 
and $3.4 \%$ protein by using NRC (17) model and programme package Version 1.1.9. The cows had ad libitum access to water.

\section{Analytical procedure}

Chemical analysis of feeds and TMRs were performed in the Laboratory for quality management EKO - LAB DOO in Belgrade. For chemical analysis, the TMR samples were collected twice weekly during the trial period. The proximate and detergent fiber analysis parameters were determined according to the AOAC methodology (18).

\section{Blood biochemical parameters}

Blood sampling was performed only at the end of trial. Approximately six hours after morning feeding, by venipuncture of $v$. coccigea, $20 \mathrm{~mL}$ of blood, from all cows in the experiment, were taken into the test tubes, and immediately transported to the laboratory in a portable freezer. Whole blood samples were centrifuged for 10 minutes at 3000 rpm and serum samples were analyzed by standard biochemical procedures. Determination of values for basic parameters of the cows metabolic profile: concentration of blood glucose, BHBA and urea, was performed using semi-automatic biochemical analyzer RT-1904C (Rayto Life and Analytical Sciences Co. Ltd) in the laboratory for diagnostic analysis of the PKB Corporation - Centre for livestock production, Belgrade.

\section{Milk yield and composition}

The milk yield and chemical composition (content of milk fat and milk protein) were determined at the end of the trial. Milk was sampled according to the internationally agreed principles ICAR (19), by using the MK V Milk Meter (Waikato Milking Systems New Zealand Ltd.). The sample $(25 \mathrm{~g} / \mathrm{kg}$ milk) was a proportional part of a total milk quantity. After milking and milk homogenization by the above mentioned sampler, the milk was poured in bottles in an amount of $100 \mathrm{~mL}$ and conserved by the addition of $0.2-0.5 \%$ of potassium dichromate $\left(\mathrm{K}_{2} \mathrm{Cr}_{2} \mathrm{O}_{7}\right)$. Milk chemical composition (content of milk fat and protein) were estimated by infrared spectroscopy using the Milko Scan 104/SN (Foss Electric, Hillerod, Denmark) in the ECO - LAB DOO laboratory in Belgrade.

\section{Statistical analysis}

In order to investigate the effects of tannin based supplement and lactation number, and interaction of these factors on metabolic profile basic parameters, the multivariate analysis of variance was used.

The significance of the tannin addition effect on production performances of the $2^{\text {nd }}$ lactation cows was estimated by Student's t-test. Statistical significance was determined at the level of $\mathrm{P}<0.05$.

For statistical analysis of the obtained results, a free version of statistical software PASW Statistics 18 SPSS Inc. package was used (20).

\section{Results}

Results of the effects of tannin supplementation, lactation number, and interaction of these factors on the values of the examined blood metabolic profile parameters (concentration of glucose, BHBA and urea) of mid-lactation dairy cows are presented in Table 2.

Blood glucose concentration was slightly increased for cows fed ration supplemented with tannin $(0.77 \%)$, which was not significant. Cows fed TMR supplemented with tannin, had markedly lower average BHBA concentration in blood and content of blood urea $(\mathrm{P}<0.05)$ in comparison to the control group (by $17.71 \%$ and $15.01 \%$, respectively). A significantly lower concentration of BHBA was found $(\mathrm{P}<0.05)$ in the group fed ration supplemented with Tanimil SCC only for the cows in the second lactation, while the blood urea concentration was significantly lowered $(\mathrm{P}<0.01)$ in the experimental group only for cows in the third lactation. In the present study it was documented that lactation number did not influence values of glucose, BHBA and urea. Results obtained in this study indicate that there is no interaction of lactation number and tannin supplement addition in TMR of mid-lactation dairy cows, regarding the effect on basic parameters of cows' metabolic profile.

Effects of tannin supplement on the cows production performances in the second lactation are presented in Table 3.

Cows in the second lactation, that were fed tannin supplemented ration had a significantly higher milk yield and higher yield of $4 \%$ fat corrected milk (FCM) when compared to cows from the control group (by 4.42 and $5.24 \%$, respectively) $(\mathrm{P}<0.05)$. Higher 
Table 2: Effect of tannin supplementation (T), lactation number $(\mathrm{L})$ and interaction of these factors $(\mathrm{T} \times \mathrm{L})$ on blood metabolic parameters at mid-lactation dairy cows (mean $\pm \mathrm{SD}$ )

\begin{tabular}{|c|c|c|c|c|c|c|c|c|c|}
\hline \multirow{3}{*}{ Parameters $^{1}$} & \multirow{2}{*}{\multicolumn{2}{|c|}{ Without tannin }} & \multirow[b]{3}{*}{ Lact. 4} & \multirow{2}{*}{\multicolumn{3}{|c|}{ Supplemented tannin }} & \multicolumn{3}{|c|}{$P$ values } \\
\hline & & & & & & & \multirow{2}{*}{$\mathrm{T}$} & \multirow{2}{*}{$\mathrm{L}$} & \multirow{2}{*}{$\mathrm{T} \times \mathrm{L}$} \\
\hline & Lact. 2 & Lact. 3 & & Lact. 2 & Lact. 3 & Lact. 4 & & & \\
\hline $\begin{array}{c}\text { Glucose } \\
(\mathrm{mmol} / \mathrm{L})\end{array}$ & $4.10 \pm 1.26$ & $3.95 \pm 0.36$ & $3.69 \pm 0.35$ & $3.77 \pm 0.29$ & $3.93 \pm 0.59$ & $3.95 \pm 0.65$ & 0.856 & 0.271 & 0.302 \\
\hline$\overline{\mathrm{X}}$ & & $3.89 \pm 0.74$ & & & $3.92 \pm 0.53$ & & & & \\
\hline $\begin{array}{c}\text { BHBA } \\
(\mathrm{mmol} / \mathrm{L})\end{array}$ & $1.11 \pm 0.34$ & $0.86 \pm 0.21$ & $0.94 \pm 0.57$ & $0.84 \pm 0.19$ & $0.82 \pm 0.35$ & $0.70 \pm 0.14$ & $0.014^{*}$ & 1.549 & 0.365 \\
\hline$\overline{\mathrm{X}}$ & & $0.96 \pm 0.39$ & & & $0.79 \pm 0.26$ & & & & \\
\hline $\begin{array}{c}\text { Urea } \\
(\mathrm{mmol} / \mathrm{L})\end{array}$ & $7.26 \pm 3.28$ & $7.15 \pm 1.38$ & $6.31 \pm 1.24$ & $6.50 \pm 1.18$ & $5.73 \pm 1.46$ & $5.50 \pm 1.76$ & $0.018 *$ & 1.732 & 0.752 \\
\hline$\overline{\mathrm{X}}$ & & $6.93 \pm 2.09$ & & & $5.89 \pm 1.50$ & & & & \\
\hline
\end{tabular}

${ }^{1}$ Mean values \pm standard deviation are showed in the same row BHBA - ß-hydroxybutyrate

* $-\mathrm{P}<0.05$

Table 3: The effect of tannin supplementation on milk yield and chemical composition (mean $\pm \mathrm{SD}$ )

\begin{tabular}{lcc}
\hline \multicolumn{1}{c}{ Parameter $^{1}$} & Diet with tannin & Diet without tannin \\
\hline Milk yield, kg/day & $38.95 \pm 4.7^{\mathrm{a}}$ & $37.30 \pm 4.1^{\mathrm{b}}$ \\
\hline 4\% FCM yield, kg/day & $37.33 \pm 4.2^{\mathrm{a}}$ & $35.47 \pm 4.0^{\mathrm{b}}$ \\
\hline Milk fat concentration, $\%$ & $3.73 \pm 0.38$ & $3.68 \pm 0.51$ \\
\hline Milk fat yield, kg/day & $1.45 \pm 0.29$ & $3.37 \pm 0.31$ \\
\hline Milk protein concentration, $\%$ & $3.20 \pm 0.12^{\mathrm{a}} \pm 0.13^{\mathrm{b}}$ \\
\hline Milk protein yield, kg/day & $1.24 \pm 0.10^{\mathrm{a}}$ & $1.16 \pm 0.11^{\mathrm{b}}$ \\
\hline Milk fat : protein ratio & 1.17 & 1.18 \\
\hline Milk lactose concentration, $\%$ & $4.63 \pm 0.10$ & $4.50 \pm 0.12$ \\
\hline
\end{tabular}

${ }^{1}$ Mean values \pm standard deviation are showed in the columns

FCM: $4 \%$ fat corrected milk calculated as $(0.4 \times \mathrm{kg}$ milk $+15 \mathrm{x} \mathrm{kg}$ milk fat)

$\mathrm{a}, \mathrm{b}$ - Values within the same row not sharing a common letter were significantly different $(\mathrm{P}<0.05)$

milk fat content, fat yield and milk lactose were also found for a group that received tannin in TMR, but determined differences were not significant. The TMR that included tannin provided a higher milk protein concentration by $2.56 \%(\mathrm{P}<0.05)$ and a higher protein yield by $6.89 \%(\mathrm{P}<0.05)$ relative to ration without tannin.

\section{Discussion}

The aim of this study was to examine the effect of using tannin supplement in ration for midlactation dairy cows and the number of lactation on metabolic profile parameters values, as well as, on the production performances of cows in the second lactation. Blood glucose concentration was analyzed since its concentration in the blood of dairy cows is important for energy balance and lactose production in the mammary gland. Determined values were within the physiological range $(21,22)$. In the present study, similar glucose levels indicated that physiological values exist in all experimental animals. Soltan (11) also reported that replacing of row soybean by processed or tannin supplemented soybean (extruding, addition of plant tannins extract and essential oils, addition of plant tannins and pelleting) in diet for dairy cows did not influence glucose 
concentration in blood serum. After addition of leaf meal mixture of different tanniferous plants, the blood glucose level of dairy cows was within the range of physiological values without marked variations (1). It was reported that tannins increase blood glucose concentration, due to their ability to modulate the activity of rumen microorganisms and consequently ruminal fermentation (9). As a result, there is a change in the ratio (\%) of volatile fatty acids, with an increase of the ruminal production of propionate, which is a precursor for glucose synthesis. In the present study, values determined for blood BHBA concentration indicate moderate mobilization of body fat reserves, because the physiological concentration of blood BHBA for lactating cows is within the range of 0.6 to $1.0 \mathrm{mmol} / \mathrm{L}$ (23). Bjerre-Harpøth et al. (24) stated that increase in the glucose level influence lowering of the blood BHBA, and in the present study a similar tendency was observed.

Concentration ofblood ureain both experimental groups of cows was within the physiological range values $(2.0-7.5 \mathrm{mmol} / \mathrm{L})$ according to Radostitis et al. (22), with markedly lower average content of blood urea in the group of cows fed TMR supplemented with tannin, which indicated more efficient protein utilization. Obtained results are in line with earlier findings $(1,25)$ that indicated reduced protein degradation and production of $\mathrm{NH}_{3}$ in rumen, and therefore, consequently, lower absorption of ammonia through the rumen wall into the blood. Dairy cows fed rations that contained processed or supplemented soybean had reduced blood urea $\mathrm{N}(4.9,6.0$ and $7.7 \%$, respectively, $\mathrm{P}<0.05)$ in comparison to the control group fed raw soybean diet (11). The lower blood urea $\mathrm{N}$ concentrations reflected improvement in nitrogenous components metabolism from diet and increased absorption of essential amino acids (26). Our results are consistent with those of Sarker et al. (27) reporting that blood urea nitrogen value did not differ significantly between cows in different lactation. However, Roussel et al. (28) found that circulating BUN levels significantly varied in respect to the lactation number. Prpic et al. (29) also found significant effects of the lactation number on metabolic profile parameters of high-yielding cows (higher urea concentration with increased lactation number). Increased urea concentration is an indicator of disproportion between rumen degradable protein intake and fermentable for the rumen microorganisms, as it indicates an increased rate of the ureagenesis in the liver which requires large amounts of energy (30).

The results of our study are in line with those of Dey and De (1) about positive impact of condensed tannins (CT) from tanniferous Ficus bengalensis leaves on milk production and milk fat content, and their additive significant positive effect on $4 \%$ fat corrected milk yield in crossbred cows during mid-lactation. Same authors also found improved milk production efficiency $(\mathrm{kg}$ of feed $/ \mathrm{kg}$ of FCM yield) $(\mathrm{P}<0.05)$ for cows fed $\mathrm{CT}$. Wanapat et al. (31) reported that CT rich cassava hay in the diet of dairy cows, may provide additional volatile fatty acids required for the synthesis of milk fat. According to Mabjeesh et al. (26) a higher percent of milk fat, in cows fed ration supplemented with tannin, was the result of additional postruminal digestion. The effect of condensed tannin in improving production characteristics can be explained by increased availability in the intestines and increased supply of tissues with the essential amino acids from protected feed proteins (32). Methionine plays an important role as a methyl donor during the synthesis of milk fat, and also as the precursor for phospholipids components i.e. choline synthesis (33). However, feeding dairy cows with the addition of large quantities of tannin, such as 100 or $200 \mathrm{~g} /$ day of commercial tannin product ( $\mathrm{QT}_{100}$ and $\mathrm{QT}_{200}$, respectively), resulted in a decrease $(\mathrm{P}<0.05)$ of the daily milk yield from 30.17 to 26.34 and $25.92 \mathrm{~kg}$ in the experimental group of cows when compared to the control (13.0 and $14.2 \%$, respectively) (34). Benchaar and Chouinard (14) reported that supplementation of diet with quebracho condensed tannin extract (Schinopsis balansae) (150 g/day, 0.45\% DM) had no effect on milk fat composition.

Supplemented tannin did not have a profound effect on the milk lactose content. As lactose is synthesized in the mammary gland directly from blood glucose, and in ruminants the gluconeogenesis is predominantly carried out from propionic acid and amino acids, increased availability of amino acids, especially methionine, lysine and amino acids with branched chains, contributes to the extensive synthesis of lactose (35).

In the present study, a somewhat higher values for milk protein concentration were found in cows from the experimental group (3.2\%) than the average value of this parameter in Holstein cows, which according to Kirovski et al. (36) is $3.06 \%$. The aim of the modern cattle production 
is to achieve protein content of $3.4 \%$ in the milk of high-yielding cows, which is in accordance with the tendency for the purchase price of milk to be based on milk protein content (37). The results obtained in our study are consistent with the results of Attia et al. (34) who claimed that using $\mathrm{QT}_{100}$ and $\mathrm{QT}_{200}$ increased $(\mathrm{P}<0.05)$ milk protein percentage (3.59\% and $3.48 \%$, respectively) when compared to the control group (3.29\%). One of the reasons for these effects is an increase in metabolic supply with the undegradable protein due to binding of proteins with $\mathrm{CT}$. The milk fat to protein ratio in our trial did not differ significantly between examined groups of cows. According to Stoop et al. (38), a fat to protein ratio lower than 1.05 reflects milk fat depression, a dietary problem causing an energy imbalance, associated with an increase in the milk fat proportion of total unsaturated fatty acids.

Unlike our results, Aguerre et al. (15) reported that the addition of a quebracho-chestnut tannin extracts (ratio 2:1) did not affect the milk yield, and also determined a trend of linear reduction in branched-chain volatile fatty acid concentration, milk protein concentration and yield, and decrease in fat-and-protein-corrected milk yield, with the increase in tannin levels in the nutrition of cows. Addition of large amounts of tannin caused a decline in milk yield, milk fat and protein concentration, showing a low potential to alter ruminal bio-hydrogenation process and to modify fatty acid profile of milk fat (14). Disagreements in the obtained results may be explained by different sources and levels of added tannins, animal physiological status and diet composition. Effects of mildly excessive CT supplementation can be tolerated for short periods (weeks), but prolonged feeding of CT can slow down digestion rates, increase rumen digesta mass and reduce productivity (39). Moreover, the addition of condensed tannin reduced digestibility of the starch, leading to a decrease in the production of volatile fatty acids, wherein the decrease in the amount of propionate limited glucose synthesis and therefore altered lactose synthesis.

\section{Conclusions}

According to the results of this study it may be concluded that mid-lactation dairy cows fed TMR supplemented with tannin had significantly lower concentrations $(\mathrm{P}<0.05)$ of blood BHBA and urea, with slightly increased concentration of glucose. There was not significant effect of the lactation number, neither interaction of the tannin supplementation in diet and lactation number on values of basic parameters of cows metabolic profile. The addition of tannin in diets for cows in the second lactation had a positive effect on milk production, content and yield of milk proteins $(\mathrm{P}<0.05)$, while differences in the content and yield of milk fat and lactose were not significant. Results of the present study indicate that tannin supplement "Tanimil SCC" may be successfully used in nutrition of lactating dairy cows, whereby added to the TMR in quantity of $40 \mathrm{~g} / \mathrm{cow} /$ day probably has protective effects on rapidly degradable dietary protein and decreases their ruminal degradation. This improves protein utilization, having a positive effect on a significant reduction of blood urea and BHBA concentrations, and improving production performances.

\section{Acknowledgments}

This research was supported by the Ministry of Science and Technological Development of the Republic of Serbia, project No. TR 31086: Optimisation of technological procedure and zootechnical resources on farms with the aim of improving the sustainability of milk production.

\section{References}

1. Dey A, De PS. Influence of condensed tannins from Ficus bengalensis leaves on feed utilization, milk production and antioxidant status of crossbred cows. Asian-Australasian J Anim Sci 2014; 27: 342-8.

2. Henke A, Dickhoefer U, Westreicher-Kristen E, et al. Effect of dietary Quebracho tannin extract on feed intake, digestibility, excretion of urinary purine derivatives and milk production in dairy cows. Arch Anim Nutr 2017; 71: 37-53.

3. Frutos P, Hervás G, Giráldez FJ, Mantecón AR. Review. Tannins and ruminant nutrition. Spanish J Agric Res 2004; 2: 191-202.

4. Patra AK, Saxena J. Exploitation of dietary tannins to improve rumen metabolism and ruminant nutrition. J Sci Food Agric 2011; 91: 24-37.

5. McSweeney CS, Palmer B, McNeill DM, Krause DO. Microbial interactions with tannins: nutritional consequences for ruminants. Anim 
Feed Sci Tech 2001; 91: 83-93.

6. Krempaský M, Maskalová I, Bujňák L, Vajda V. Ketone bodies in blood of dairy cows: prevalence and monitoring of subclinical ketosis. Acta Vet Brno 2014; 83: 411-6.

7. Lager K, Jordan E. The metabolic profile for the modern transition dairy cow. In: The MidSouth Ruminant Nutrition Conference. Grapevine, Texas, 2012: 9-16.

8. Broderick GA, Clayton MK. A statistical evaluation of animal and nutritional factors influencing concentrations of milk urea nitrogen. J Dairy Sci 1997; 80: 2964-71.

9. Szczechowiak J, Szkudelska K, Szumacher-Strabel M, et al. Blood hormones, metabolic parameters and fatty acid proportion in dairy cows fed condensed tannins and oils blend. Ann Anim Sci 2018; 18: 155-66.

10. Wang Y, Douglas GB, Waghorn GC, Barry TN, Foote AG. Effect of condensed tannins in Lotus corniculatus upon lactation performance in ewes. J Agr Sci 1996; 126: 353-62.

11. Soltan MA. Rumen fermentation characteristics and lactation performance in dairy cows fed different rumen protected soybean meal products. Pakistan J Nutr 2009; 8: 695-703.

12. Anantasook N, Wanapat M, Cherdthong A, Gunun P. Effect of tannins and saponins in Samanea saman on rumen environment, milk yield and milk composition in lactating dairy cows. J Anim Physiol Anim Nutr 2015; 99: 335-44.

13. Huang Q, Liu X, Zhao G, Hu T, Wang Y. Potential and challenges of tannins as an alternative to in-feed antibiotics for farm animal production. Anim Nutr 2018; 4(2): 137-50.

14. Benchaar C, Chouinard PY. Assessment of the potential of cinnamaldehyde, condensed tannins, and saponins to modify milk fatty acid composition of dairy cows. J Dairy Sci 2009; 92: 3392-6.

15. Aguerre $\mathrm{MJ}$, Capozzolo $\mathrm{MC}$, Lencioni $\mathrm{P}$, Cabral C, Wattiaux MA. Effect of quebracho-chestnut tannin extracts at 2 dietary crude protein levels on performance, rumen fermentation, and nitrogen partitioning in dairy cows. J Dairy Sci 2016; 99: 4476-86.

16. Broderick GA, Grabber JH, Muck RE, Hymes-Fecht UC. Replacing alfalfa silage with tannin-containing birdsfoot trefoil silage in total mixed rations for lactating dairy cows. J Dairy Sci 2017; 100: 3548-62.

17. NRC. Nutrient requirements of dairy cattle. $7^{\text {th }}$ rev. ed. Washington : National Academy Press, 2001. https://books.google.rs/books?ISBN=0309515211

18. AOAC International. Official methods of analysis. $17^{\text {th }}$ ed. Arlington : AOAC International, 2002.

19. ICAR. International Committee for Animal Recording. Analytical methods used in milk recording, 2005. https://www.icar.org/documents/ milk_laboratories_leray/list_analytical_methods_ in_milk_recording.pdf

20. SPSS. PASW statistics 18 software. Demo version of software 2016. Hong Kong : SPSS, 2009. https://www.spss.com/Registration/premium/consol056.cfm? Demo_id=37

21. Kaneko JJ, Harvey JW, Bruss ML. Clinical biochemistry of domestic animals. 5th ed. San Diego : Academic Press, 1997.

22. Radostitis OM, Gay CC, Blood DC, Hinchkliff KW, Constable PD. Rumen acidosis. In: Veterinary medicine: a textbook of the diseases of cattle, horses, sheep, pigs and goats. 10th ed. London : Saunders Elsevier, 2007: 314-25.

23. Ospina PA, Nydam DV, Stokol T, Overton TR. Evaluation of nonesterified fatty acids and B-hydroxibutirate in transition dairy cattle in the northeastern United States: critical thresholds for prediction of clinical diseases. J Dairy Sci 2010; 93: 546-54.

24. Bjerre-Harpøth V, Friggens NC, Thorup VM, et al. Metabolic and production profiles of dairy cows in response to decreased nutrient density to increase physiological imbalance at different stages of lactation. J Dairy Sci 2012; 95: 2362-80.

25. Allam AM, Nagadi SA, Bakhashwain AA, Sallam SMA. Impact of sub-tropical grass grown in arid region on methane emission, milk yield and composition in dairy cows. Food Agric Environ $2013 ; 11: 620-5$.

26. Mabjeesh SJ, Galindez J, Kroll O, Arieli A. The effect of roasting nonlinted whole cottonseedon milk production by dairy cows. J Dairy Sci 2000; 83: 2557-63.

27. Sarker MSK, Islam MA, Huque KS, Sarker NR, Hossain MM, Bhuiyan AA. Effect of genotype and lactation on milk urea nitrogen, blood urea nitrogen and milk composition of dairy cows. Bangladesh J Livest Res 2012; 19: 74-84.

28. Roussel, JD, Rahmanian MS, Guthrie LD, Musgrave SD. Effects of lactation on various blood parameters in Holstein cows. I. Serum protein and protein fractions. Prof Anim Sci 1988; 4: 9-15.

29. Prpić Z, Konjačić M, Vnučec J, Ramljak 
J, Ivanković A. Nehranidbeni čimbenici sadržaja ureje u mleku. Stočarstvo 2005; 59: 173-87.

30. Oetzel GR. Monitoring and testing dairy herds for metabolic diseases. Vet Clin North Am Food Anim Pract 2004; 20: 651-74.

31. Wanapat M, Puramongkon T, Siphuak W. Feeding of cassava hay for lactating dairy cows. Asian-Aus J Anim Sci 2000; 13: 478-82.

32. Garg MR, Sherasia PL, Bhanderi BM, Gulati SK, Scot TW. Effect of feeding rumen protected protein on milk production in low yielding crossbred cows. Anim Nutr Feed Technol 2005; 5: 1-18.

33. Sharma BK, Erdman RA. Abomasal infusion of choline and methionine with or without 2-amino-2-methyl-1-propanol for lactating dairy cows. J Dairy Sci 1988; 71: 2406-11.

34. Attia MFA, Nour El-Din ANM, El-Zarkouny SZ, El-Zaiat HM, Zeitoun MM, Sallam SMA. Impact of Quebracho tannins supplementation on productive and reproductive efficiency of dairy cows. Open J Anim Sci 2016; 6: 269-88.

35. Joksimović Todorović M, Davidović V. Changes in white blood pictures and some bio- chemical parameters of dairy cows in peripartum period and early lactation. Mljekarstvo 2012; 62: $151-8$.

36. Kirovski D, Šamanc H, Prodanović R. Procena energetskog statusa krava na osnovu koncentracije masti, proteina i uree u mleku. Vet Glasn 2012; 66: 97-110.

37. Orešnik A. Uticaj ishrane na proizvodnju i sastav mleka, zdravstveno stanje i plodnost visokomlečnih krava. In: Clinica Veterinaria 2009: zbornik radova XI. regionalnog savetovanja iz kliničke patologije i terapije životinja. Subotica, 2009: 27-36.

38. Stoop WM, Bovenhuis H, Heck JML, van Arendonk JAM. Effect of lactation stage and energy status on milk fat composition of Holstein-Friesian cows. J Dairy Sci 2009; 92: 1469-78.

39. Grainger C, Clarke T, Auldist MJ, et al. Potential use of Acacia mearnsii condensed tannins to reduce methane emissions and nitrogen excretion from grazing dairy cows. Can J Anim Sci 2009; 89: 241-51.

\title{
UČINEK PREHRANSKEGA DODATKA S TANINOM V PREHRANI KRAV SREDI LAKTACIJE NA PARAMETRE PRESNOVNEGA PROFILA IN NJIHOVE PROIZVODNE LASTNOSTI
}

\author{
V. Davidović, B. Jovetić, M. Joksimović Todorović, B. Stojanović, M. Lazarević, P. Perišić, M. Radivojević, M. Maletić, A. \\ Miletić
}

Povzetek: Cilj študije je bil proučiti učinek dodajanja tanina v obroku pri kravah molznicah sredi laktacije ( $90 \pm 17$ dni v mleku) in števila dojenj telet na nekatere parametre presnovnega profila. Poleg tega je bil ovrednoten tudi učinek dodajanja tanina na proizvodne lastnosti krav v drugi laktaciji. Raziskave so bile izvedene pri 80 kravah pasme Holstein, razdeljenih v dve skupini po 40 krav (kontrolna in poskusna skupina), ki so vključevale 16 krav v2. in 12v 3. in 4. laktaciji. Dodatek tanina Tanimil SCC (40 $\mathrm{g} / \mathrm{kravo} /$ dan; 40 \% taninov) je bil dodan v skupni mešani obrok (TMR) poskusne skupine, medtem ko je bila kontrolna skupina krav krmljena brez dodatka tanina. Poskus je trajal 60 dni. Krave molznice, hranjene s krmo z dodanimi tanini, so imele izrazito nižje vrednosti $(P<0,05)$ koncentracije B-hidroksibutirata $(0,79$ v primerjavi z $0,96 \mathrm{mmol} / \mathrm{L})$ in nižjo koncentracijo sečnine $v$ krvi (5,89 v primerjavi z 6,93 mmol/L). Razlika v koncentraciji glukoze $v \mathrm{krvi} \mathrm{(3,92} \mathrm{v} \mathrm{nasprotju} \mathrm{z} 3,89 \mathrm{mmol} / \mathrm{L})$ ni bila statistično značilna. Dojenje ni značilno vplivalo na vrednosti parametrov presnovnega profila (koncentracije glukoze, B-hidroksibutirata in sečnine). Medsebojni vpliv števila laktacij in dodatka tanina na vrednosti pregledanih parametrov presnovnega profila ni bil statistično značilen. Dopolnilo tanina v krmi krav v drugi laktaciji je imelo pozitiven učinek $(P<0,05)$ na mlečnost $(4,42 \%)$ in na količino mleka s popravljeno vrednostjo 4-odstotne maščobe (FCM, 5,24\%). Uporaba tanina je izboljšala koncentracijo beljakovin (3,20 v primerjavi z 3,12\%) in izkoristek mlečnih beljakovin (od 1,16 do 1,24 kg/dan) ( $P<0,05)$. Dodatek tanina je izboljšal tudi koncentracijo in izkupiček mlečne maščobe ter koncentracijo laktoze. Dodatek Tanimila SCC kravam na sredini laktacije je pozitivno vplival na znižanje vsebnosti ß-hidroksibutirata in sečnine v krvi ter izboljšal produktivnost krav v drugi laktaciji.

Ključne besede: tanini; kravevlaktaciji; prehrana; presnovni profil; mlečnostin sestava mleka 